\title{
Assessment of the Process of Movement of Xylella fastidiosa Within Susceptible and Resistant Grape Cultivars
}

\author{
C. Baccari and S. E. Lindow
}

Department of Plant and Microbial Biology, University of California, Berkeley. Accepted for publication 23 August 2010.

\begin{abstract}
Baccari, C., and Lindow, S. E. 2011. Assessment of the process of movement of Xylella fastidiosa within susceptible and resistant grape cultivars. Phytopathology 101:77-84.

To better understand the processes contributing to symptoms and resistance to Pierce's disease of grape, we examined the movement and multiplication of a green fluorescent protein-marked strain of Xylella fastidiosa in the stems and petioles of Cabernet Sauvignon, Chenin Blanc, Roucaneuf, and Tampa grape cultivars that differ in their susceptibility to this disease. $X$. fastidiosa achieved much lower population sizes and colonized fewer xylem vessels in the stem of resistant cultivars compared with more susceptible cultivars. In contrast, $X$. fastidiosa achieved similarly high population sizes and colonized a similar proportion of the vessels in petioles of susceptible and resistant cultivars, suggesting that, compared with the stem, X. fastidiosa is relatively

unrestricted in its movement and growth within the petiole. There was not a direct relationship between the population size of $X$. fastidios $a$ in the stem and the proportion of vessels colonized; a much higher population size of the pathogen was observed in susceptible cultivars than expected based on the proportion of vessels colonized. The high population sizes of $X$. fastidiosa in stems of susceptible genotypes were associated with both a high number of infected vessels and a much higher extent of colonization of those vessels that become infested than in more resistant cultivars. The formation of large cellular aggregates in vessels is not required for $X$. fastidiosa to move laterally in the stem to adjacent vessels because most vessels harbored only small assemblages, especially in resistant cultivars such as Roucaneuf, in which some intervessel movement was detected. Resistance to Pierce's disease is apparently not due to inhibitory compounds that circulate in the xylem because they might be expected to operate similarly in all tissues.
\end{abstract}

Pierce's disease (PD), a chronic problem in the grape industry in California, is now a potentially more devastating disease due to the introduction of the glassy-winged sharpshooter, a more effective vector of the pathogen Xylella fastidiosa than native vectors. The management of this disease is difficult because the vascular colonization of grapevines by the pathogen limits its accessibility to bactericides. Many other agriculturally important plants such as citrus, almond, alfalfa, and coffee, as well as many ornamental plants, are also susceptible to diseases caused by $X$. fastidiosa $(15,24)$.

$X$. fastidiosa is transmitted to new host plants during xylem sap feeding by sharpshooter vectors and then multiplies and spreads from the site of inoculation to colonize the xylem, a watertransport network of vessels composed of dead, lignified cells. Vessels are interconnected by bordered pits that allow the passage of xylem sap but block passage of larger objects due to the presence of the pit membrane $(6,7,29)$. Cells of the pathogen multiply and attach to the vessel walls, forming biofilm-like colonies that can, when sufficiently large, occlude xylem vessels, blocking water transport $(2,11,19,24,30)$. In susceptible plants, leaf scorching, fruit shriveling, and other symptoms increase with time, likely due to water stress caused by xylem blockage. A much higher proportion of vessels in symptomatic tissues are colonized by $X$. fastidiosa than in nonsymptomatic tissues, suggesting that the disease is a progressive one associated with increasing levels of colonization of vessels $(2,3,19,23)$. Although $X$. fastidiosa can colonize many plant species asymptomatically, a

Corresponding author: S. E. Lindow; E-mail address: icelab@berkeley.edu

* The $e$-Xtra logo stands for "electronic extra" and indicates that Figure 1 appears in color online.

doi:10.1094/PHYTO-04-10-0104

(C) 2011 The American Phytopathological Society high incidence of vessel colonization is seen only in plants such as grape that exhibit signs of disease $(8,11,23,24)$. The population size of $X$. fastidiosa in grapevines resistant and susceptible to PD is highly correlated with symptom expression $(2,11,12,14,17)$. However, we still lack an understanding of the process of colonization and how high populations of $X$. fastidiosa lead to symptom development.

In order for water movement in a grape stem to be sufficiently restricted that disease develops, a large percentage of the xylem pathways must be blocked. Although $>40 \%$ of the xylem vessels in a given cross-section of an infected grape stem may be infested with $X$. fastidiosa $(19,30)$ this alone is unlikely to explain water stress. However, sequential sections of grape tissue reveal that different xylem vessels are blocked in different cross-sections, and the cumulative percentage of occluded vessels in one of several sections along a 5-mm section of petiole was as much as five times that of a single cross-section (30). This suggests that the likelihood of blockage of flow through a xylem vessel will increase nonlinearly with the proportion of occluded vessels as secondary and tertiary paths for water movement are blocked. Although tyloses have been noted in infected grape, it has been suggested that they neither limit the spread of $X$. fastidiosa nor account for resistance in Vitis arizonica, V. Samllina, or V. rufotomentosa $(9,10)$. Given that inoculation of grape with $X$. fastidiosa usually occurs at a relatively few sites on a vine, it is clear that the pathogen has the ability to move extensively both axially and radially in xylem tissues. Such movement is presumably sequential, and must take some time, explaining why the disease is "progressive" and appears only several weeks after inoculation.

Although dispersion of $X$. fastidiosa through the plant apparently follows the natural course of the xylem vessels, the pathogen requires a mechanism for breaching vessels connected by bordered pits because they do not readily allow passage of objects $\geq 20 \mathrm{~nm}$ (6). Considerable evidence suggests that $X$. 
fastidiosa degrades pit membranes to traverse bordered pits (22). $X$. fastidiosa expresses genes predicted to encode pit membranedegrading enzymes such as endoglucanases and polygalacturonases in vitro (1). Furthermore, a mutant blocked in production of polygalacturase was unable to move within grape and, thus, was avirulent (23). In addition, transgenic grapes expressing a pear polygalacturonase-inhibiting protein exhibited more resistance to $X$. fastidiosa than did untransformed plants (1).

Although the progressive colonization of xylem vessels is associated with disease, the nature of this process in resistant plants compared with more susceptible plants is poorly understood. Nearly all studies of $X$. fastidiosa colonization of grape have focused on the petioles, with little examination of its movement and distribution in the stems. Importantly, recent work has noted that the mechanism of resistance to X. fastidiosa is localized within the stem xylem and not fully functional or absent in the xylem of petioles and leaf blades (17). They speculated that a resistance mechanism based on nutritional or structural differences between resistant and susceptible types restricts the growth and movement of the pathogen in the stem xylem. Given that, in resistant grapes cultivars as well as other plant species, $X$. fastidiosa can exhibit systemic infection but attains relatively low population sizes (17), the process of movement in plants presumably is a quantitatively highly variable one. Our study was designed to examine differences in the colonization process of the stem of different grape genotypes to identify resistance mechanisms. We exploited the ability to rapidly and quantitatively assess the presence of a green fluorescent protein (gfp)-marked strain of $X$. fastidiosa by fluorescence microscopy so that the process of multiplication and movement of the pathogen in plants differing in resistance could be related to each other.

\section{MATERIALS AND METHODS}

Bacterial strains and culture conditions. A gfp-marked strain of $X$. fastidiosa strain Temecula (19) was recovered from infected petioles of Cabernet Sauvignon grape. Petioles were surface sterilized and macerated, and appropriate dilutions of the macerate were plated onto solidified PWG media supplemented with kanamycin $(30 \mu \mathrm{g} / \mathrm{ml})$ as previously described (20). Cells of $X$. fastidiosa were harvested by scraping from PWG plates containing kanamycin, suspended in succinate citrate phosphate (SCB) buffer (13), and diluted to a concentration of $10^{8}$ cells $/ \mathrm{ml}$ in SCB buffer to yield inoculum for plant inoculation.

Plant inoculations. Greenhouse-grown V. vinifera Cabernet Sauvignon and Chenin Blanc grapevines (susceptible cultivars) and Roucaneuf and Tampa (resistant cultivars) were mechanically inoculated by puncturing a droplet of inoculum placed on a stem with an insect-mounting needle as in other studies (13). Roucaneuf is a complex hybrid that includes $V$. cinerea and $V$. berlandieri and has been described as "fully resistant" to PD under field conditions, whereas Tampa is also described as resistant (17). In total, 12 plants of each genotype were inoculated, to enable 4 to be sampled at each of three times after inoculation. Self-rooted plants derived from segments of dormant vines or from green cuttings were stem inoculated with 5- $\mu$ d drops of bacterial cell suspension $\left(10^{8}\right.$ cells $\left./ \mathrm{ml}\right)$ when they were $\approx 40 \mathrm{~cm}$ tall and kept in a greenhouse with daytime temperatures of $\approx 28^{\circ} \mathrm{C}$. Stems and nearby petioles from four plants of each genotype were sectioned at the point of inoculation and at 30,60, and $120 \mathrm{~cm}$ away from the point of inoculation at 6,11 , and 16 weeks after inoculation. Stem and petiole samples each consisted of a segment $1 \mathrm{~cm}$ in length that was weighed and then surface sterilized. $X$. fastidiosa populations were estimated by dilution plating of macerates of stem segments in SCB buffer on PWG as in other studies (24).

Microscopy of plant tissues. Petiole and stem segments from plants treated as above were sectioned and prepared for micro- scopy by methods similar to that used by Newman et al. (19). Individual hand-sectioned stem or petiole cross-sections were mounted on a microscope slide and immersed in a $50 \%$ glycerol solution. Microscopic evaluation was done with $\times 5$ and $\times 10$ magnification on an AxioImager 373 Epifluorescence microscope. GFP fluorescence was captured using a 505- to 550-nm band pass filter for petiole cross-section images while stem crosssections were imaged using a filter optimized for use with fluorescein isothiocyanate using a 490- to 528-nm band. Twelve sequential cross-sections were prepared from tissues immediately adjacent to each of the stem or petiole segments in which population sizes of $X$. fastidiosa were determined from dilution plating of tissue macerates. The total number of vessels in a given cross-section as well as the number of infested vessels was counted. On average, $\approx 300$ to 400 vessels were present in each stem cross-section and $\approx 150$ to 200 vessels were present in a typical petiole. The number of colonized vessels was averaged for each sampling location and grape genotype and normalized for the average number of total vessels per section. Multiple comparisons among treatment effects were made using a least significant difference test. All analyses were performed using Statistica (Statsoft Inc., Tulsa, OK).

The extent of colonization of individual stem xylem vessels was also assessed by similar methods. Hand-sectioned crosssections were examined as above but at a magnification of $\times 20$ and $\times 40$ to enable better estimation of the number of cells present in each vessel. The number of cells in cellular aggregates was estimated similarly to that of Newman et al. (19). The number of cells colonizing a given vessel section was estimated by determining the cross-sectional area of the $X$. fastidiosa cell assemblage as well as its depth, estimated by focusing up and down before capturing an image. Representative images for which the number of cells in aggregates of a given size class were separately quantified under higher magnification were used to assist visual estimates of aggregate size.

We distinguished between those vessels having high levels of colonization (which we estimated to be $\approx 100,000$ cells/ vessel), those moderate levels of colonization $(\approx 1,000$ cells/vessel $)$, or low levels of colonization ( $<10$ cells/vessel). In all, $\approx 300$ to 400 vessels were present in each stem section of each genotype; in total, $\approx 10,000$ vessels were examined for each genotype. Statistical analysis of the data was as described above.

\section{RESULTS}

Colonization of petioles and stems of resistant and susceptible grape by $\boldsymbol{X}$. fastidiosa. Colonization of susceptible Cabernet Sauvignon and Chenin Blanc as well as the resistant genotypes Tampa and Roucaneuf by a gfp-marked $X$. fastidiosa strain was examined by paired culturing and epifluorescence microscopy at various times and distances from the point of inoculation, so that the processes of growth and movement in the plants could be separately assessed. There were no obvious differences in the overall anatomy of the stem and petiole tissues of the resistant and susceptible cultivars that were apparent by fluorescence microscopy (Fig. 1). The cultivars differed, however, in the number and timing of appearance of tyloses in the stem tissue. Although Tampa and Roucaneuf harbored abundant tyloses by as soon as 6 weeks after inoculation, the susceptible cultivars produced tyloses only much later (11 to 16 weeks after inoculation). The incidence of tyloses was greatest in stems near the point of inoculation but at least some were seen throughout the length of the stem tissue examined. Tyloses were more commonly seen in stem tissues than in petioles, especially in resistant grape cultivars.

The incidence of infestation of stem xylem vessels by $X$. fastidiosa was directly related to the resistance of these cultivars to PD. The resistant cvs. Roucaneuf and Tampa exhibited far 

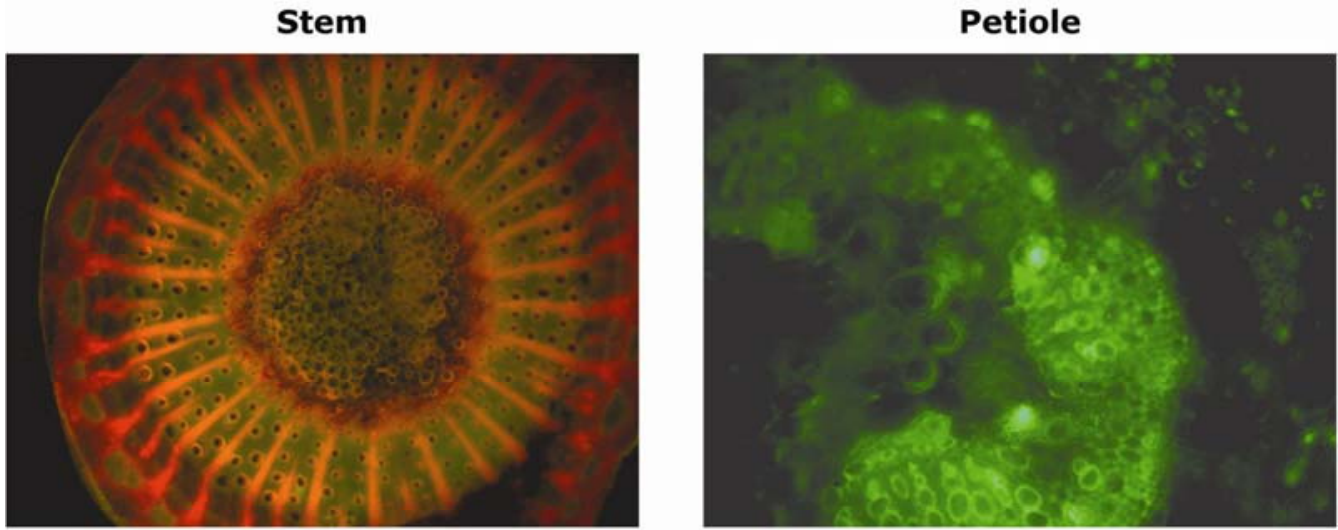

Roucaneuf
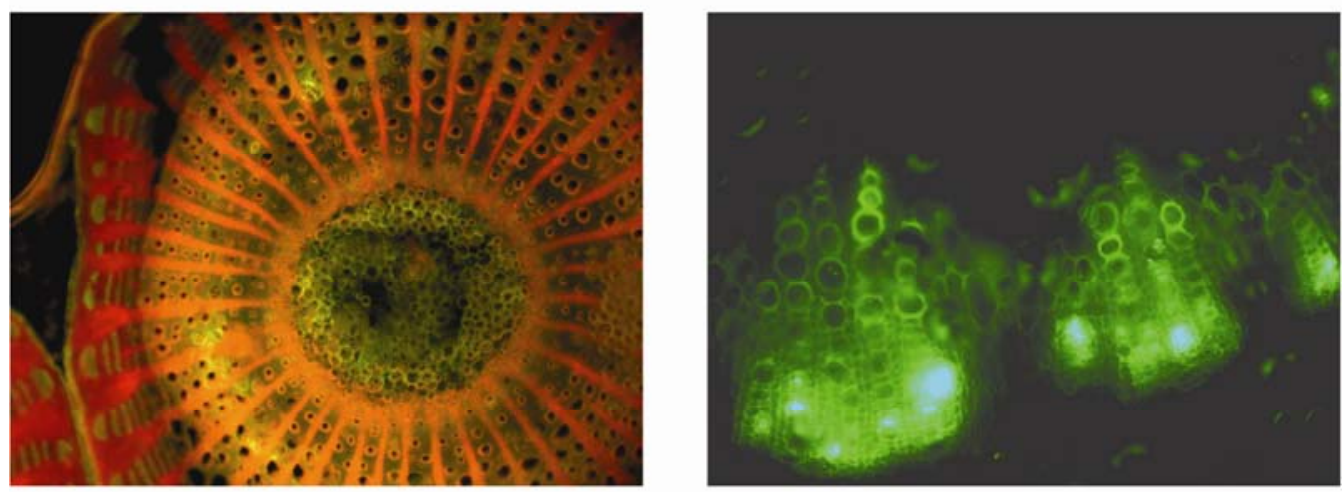

\section{Tampa}
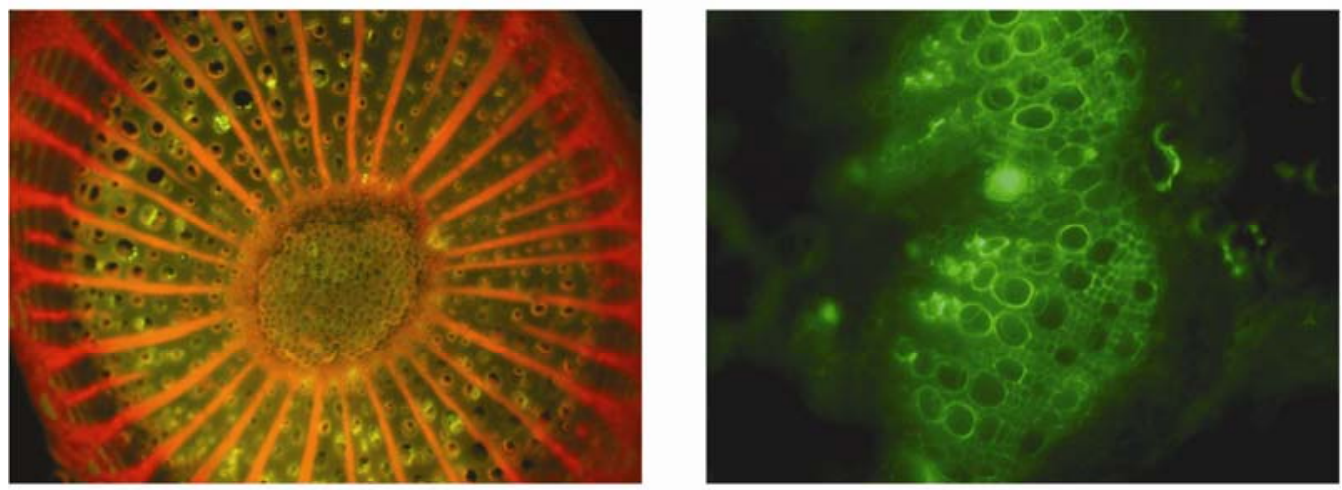

\section{Cabernet Sauvignon}
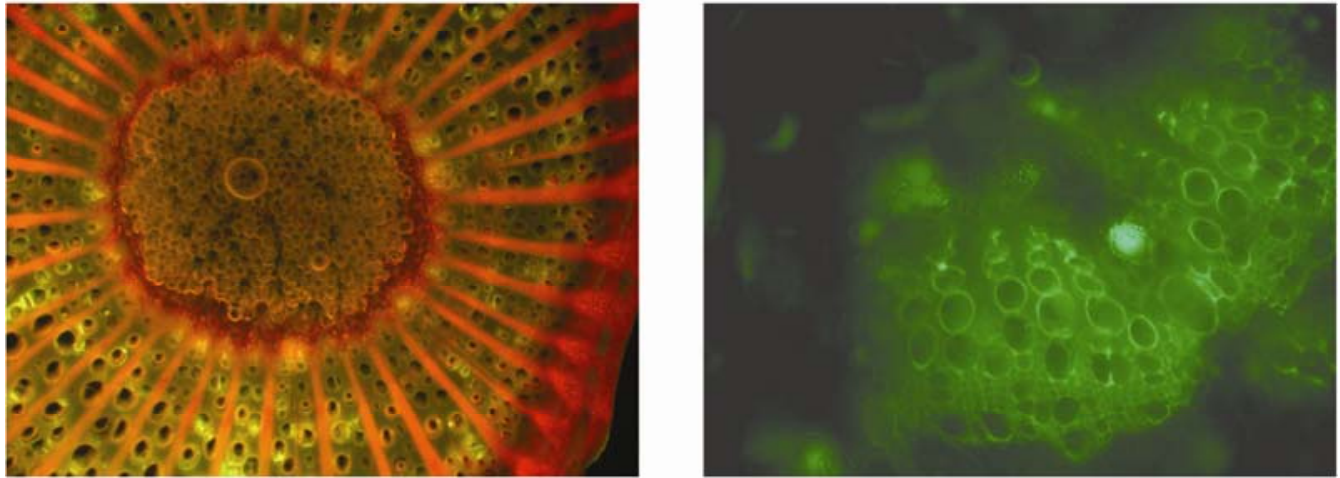

\section{Chenin Blanc}

Fig. 1. Visualization of stem tissues (left column) and petioles (right column) of the susceptible grape cvs. Cabernet Sauvignon and Chenin Blanc and the resistant cvs. Tampa and Roucaneuf that were inoculated with a green fluorescent protein-marked strain of Xylella fastidiosa. Plants were sampled 11 weeks after inoculation. 
fewer symptoms than the susceptible cultivars and only near the point of inoculation. The highest incidence of colonization of vessels was observed in the highly susceptible Cabernet Sauvignon, with the lowest in the most resistant cv. Roucaneuf (Figs. 1 and 2). A very low proportion of the stem vessels at sites away from the point of inoculation of the most highly resistance cv. Roucaneuf were colonized by any cells of $X$. fastidiosa compared with that of Cabernet and Chenin Blanc whereas Tampa exhibited an intermediate level of colonization (Figs. 1 and 2). It was apparent that, near the point of inoculation, the proportion of vessels that harbored any number of cells of $X$. fastidiosa was higher than at more distal sites. With increasing time since inoculation, the number of vessels colonized also increased in the susceptible cultivars; this effect was less pronounced in the more resistant cultivars because the overall incidence of infestation was much lower (Fig. 2). The reduced proportion of colonized vessels in resistant genotypes, particularly at distal sites, presumably reflects a reduced intervessel movement in the resistant cultivars.

In contrast to stem tissue, petioles of all four cultivars were equally well colonized by the gfp-tagged cells of $X$. fastidiosa, and the incidence of vessel colonization was substantially higher than that of the stem tissues at a given distance from the point of inoculation (Fig. 1). There was no significant difference in population size of $X$. fastidiosa between the resistant and susceptible genotypes in the petioles detected by culturing (data not shown). Similar results have been previously observed $(14,17)$. Thus, the petioles seem to offer less resistance to movement and multiplication of $X$. fastidiosa compared with stem tissue.

\section{CABERNET SAUVIGNON}

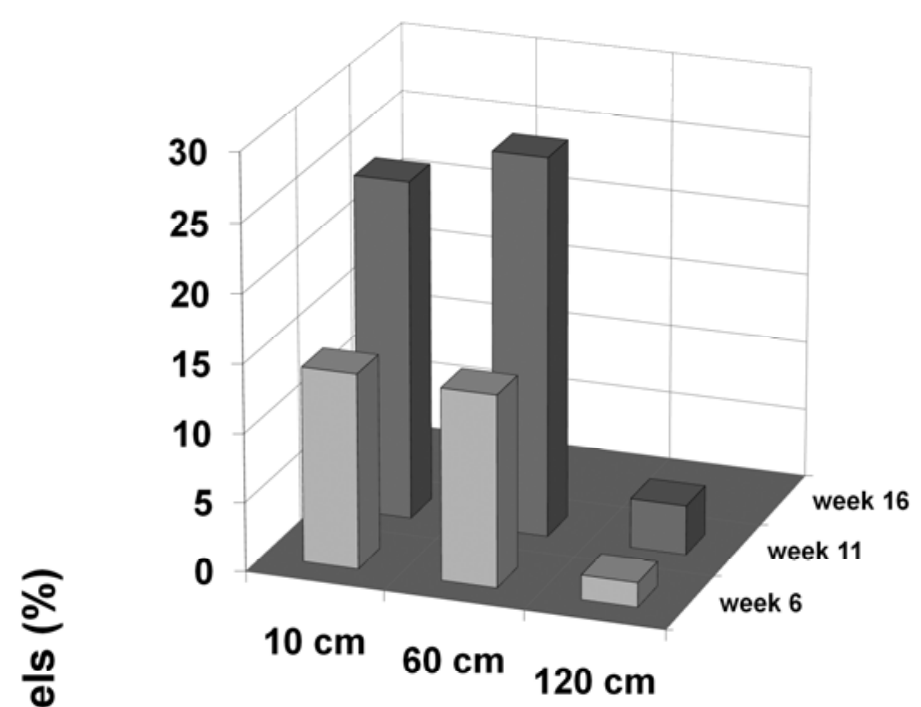

ROUCANEUF

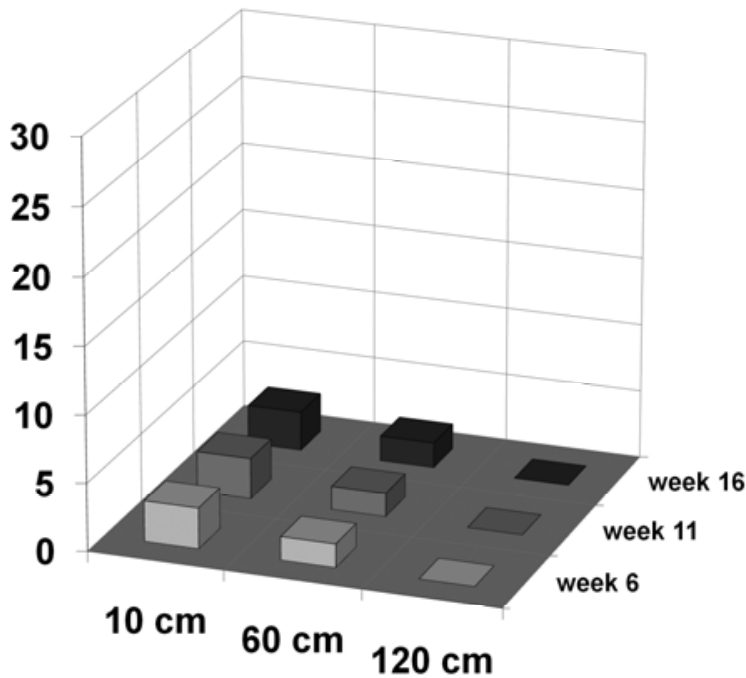

\section{CHENIN BLANC}

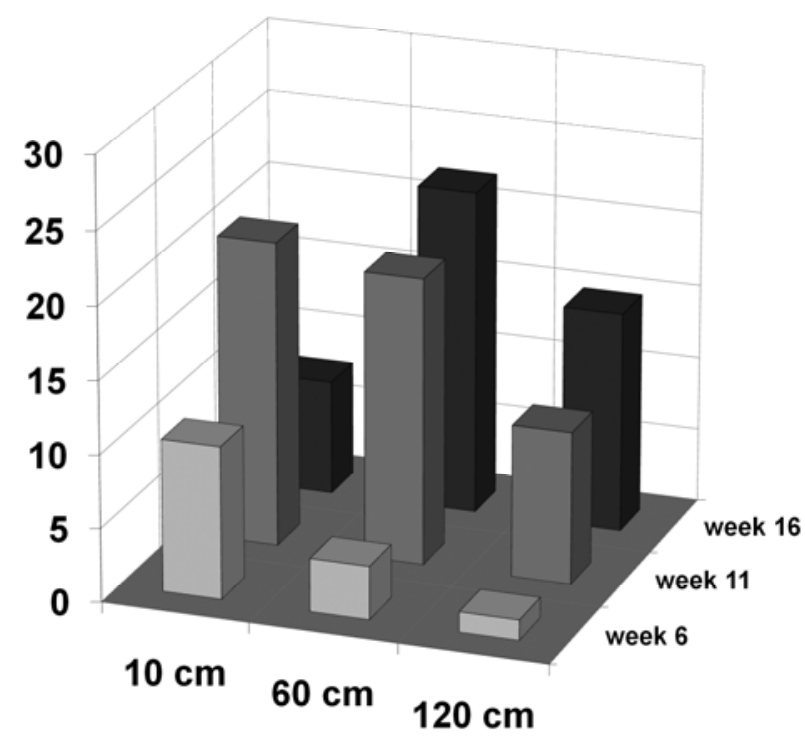

TAMPA

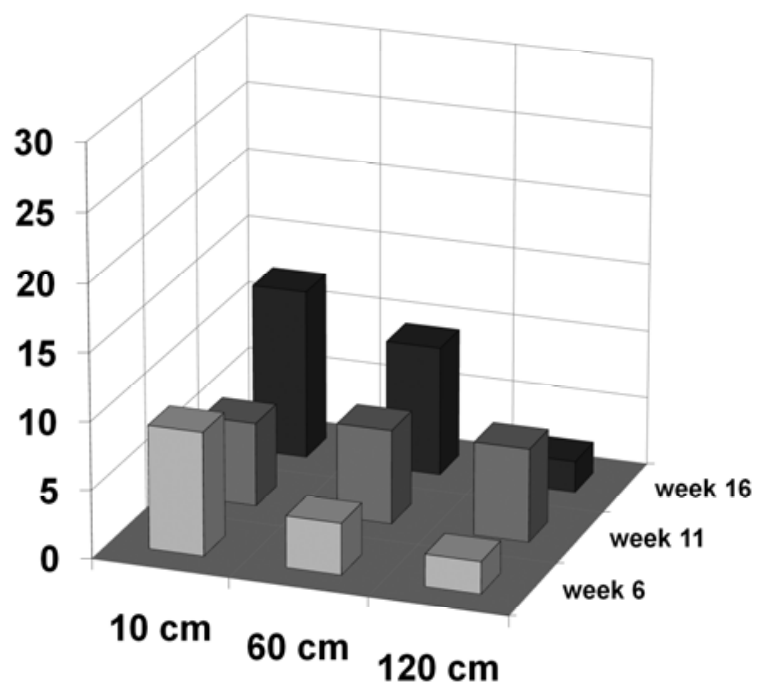

Distance from point of inoculation

Fig. 2. Percentage of stem xylem vessels of the susceptible grape cvs. Cabernet Sauvignon and Chenin Blanc and the resistant cvs. Tampa and Roucaneuf that were colonized by at least one cell of a green fluorescent protein-marked strain of Xylella fastidiosa as determined by fluorescence microscopy. Plants were sampled at different times after inoculation and at various distances from the point of inoculation. 
The numbers of cells in vessels of different grape cultivars determined by culturing small stem segments were nonlinearly related to the proportion of vessels colonized as determined by microscopic detection of a gfp-marked $X$. fastidiosa. Although the population size of $X$. fastidiosa detected in the stems of Cabernet and Chenin Blanc was as much as 100 -fold greater than that in Roucaneuf and Tampa, only approximately twice as many vessels were colonized (Fig. 3). Thus, a much higher population size of $X$. fastidiosa was observed in susceptible cultivars than expected based on the relative number of infested vessels in a stem. This suggested that there may be substantial differences in the average population size of $X$. fastidiosa in a given infested vessel in different grape cultivars.

To address whether $X$. fastidiosa not only moves into more vessels of susceptible grape cultivars than resistant cultivars but also multiplies more extensively in those vessels into which it moves, we estimated the extent of colonization of each vessel that was infested with a gfp-marked strain using fluorescence microscopy. We distinguished between those stem vessels having high levels of colonization, which we estimated to be $\approx 100,000$ cells/vessel, from those having moderate levels of colonization $(\approx 1,000 \mathrm{cells} / \mathrm{vessel})$ or those having minor colonization $(\leq 10$ cells/vessel). The colonization of each vessel in a given crosssection was assessed by fluorescence microscopy for each cultivar at several different times and distances from the point of inoculation. A large variation in the extent of colonization of individual vessels in a given section was observed for all cultivars. In all cultivars, the large majority of vessels harbored relatively few cells of $X$. fastidiosa (Fig. 4). On average, for all cultivars, $\approx 10$ fold more vessels harbored at least a few cells of $X$. fastidiosa than those that harbored moderate numbers of cells. Vessels that harbored high numbers of $X$. fastidiosa cells were only observed in the most susceptible cv. Cabernet Sauvignon (Fig. 4). Likewise, the more susceptible cvs. Cabernet Sauvignon and Chenin Blanc both had much higher proportions of vessels that harbored moderate numbers of cells of $X$. fastidiosa than the more resistant cultivars (Fig. 4). These differences in extent of colonization were highly statistically different between cultivars in most cases (Table 1). For all cultivars, the proportion of vessels that harbored even low numbers of cells of $X$. fastidios $a$ decreased with distance from the point of inoculation. Although at least some vessels

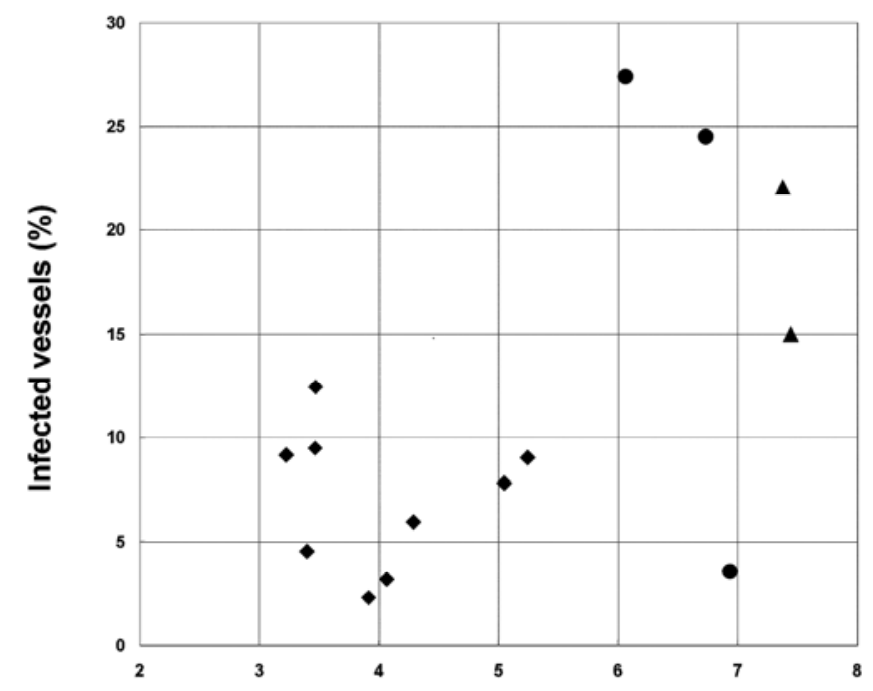

Xylella fastidiosa recovered [log(cells/g)]

Fig. 3. Relationship between the incidence of colonization of stem xylem vessels of Cabernet Sauvignon ( $)$, Tampa $(\bullet)$, and Chenin Blanc $(\boldsymbol{\Delta})$ by a green fluorescent protein-marked Xylella fastidiosa strain as determined by fluorescence microscopy and the population size of $X$. fastidiosa determined in closely adjacent tissues by culturing of stem macerates (abscissa). having at least a few cells per vessel were observed in samples as far as $120 \mathrm{~cm}$ from the point of inoculation, no vessels harbored moderate cell numbers at this sampling distance (Table 1). Although the ratio of the number of vessels harboring small numbers of cells to that of vessels harboring moderate numbers of
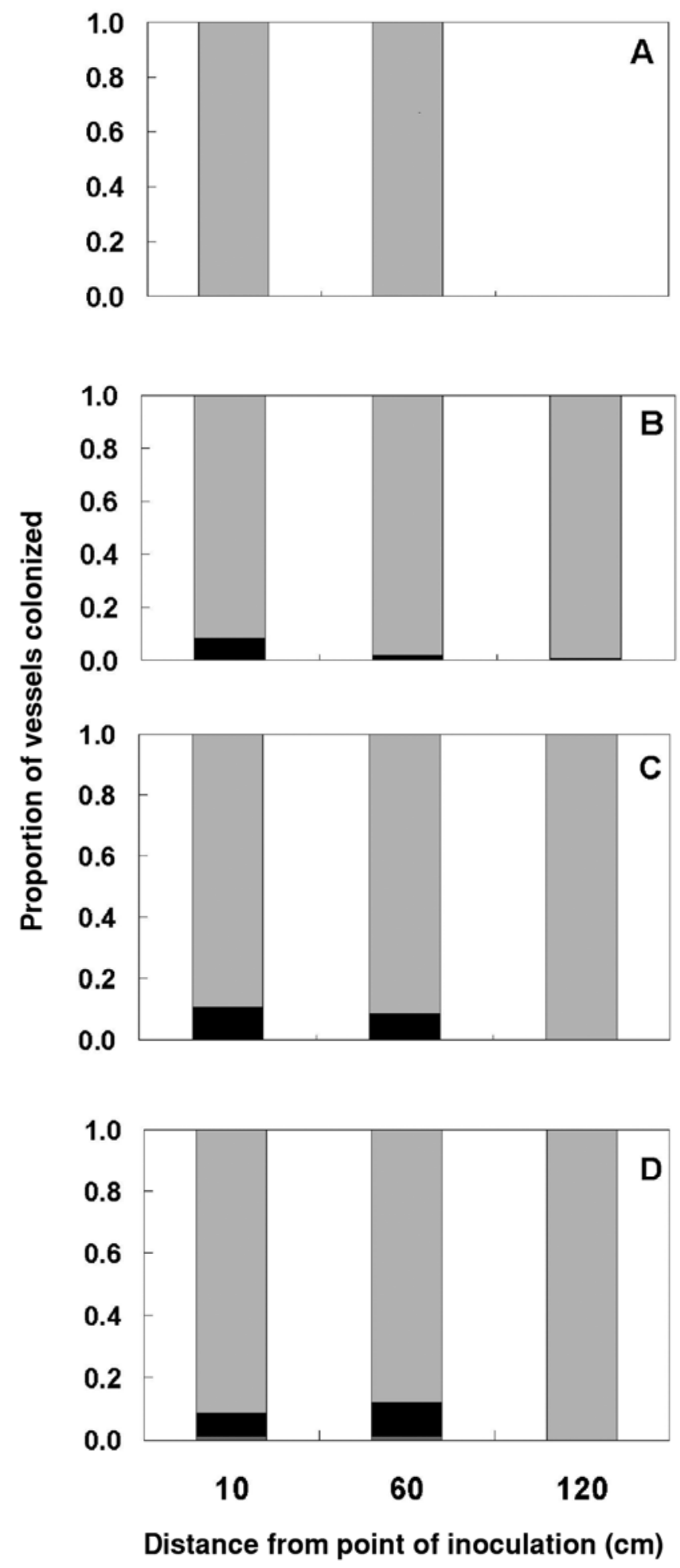

Fig. 4. Extent of colonization of the stem xylem vessels of the susceptible grape cvs. A, Cabernet Sauvignon and B, Chenin Blanc and the resistant cvs. $\mathbf{C}$, Tampa and D, Roucaneuf by a green fluorescent protein-marked strain of Xylella fastidiosa. Plants were sampled at various locations distal to the point of inoculation 11 weeks after inoculation. Shown are the proportion of vessels that harbored at least one cell of $X$. fastidiosa that exhibited only low levels of colonization ( $<10$ cells) (light bars) or moderate levels of colonization $(>10$ but $<1,000$ cells) (dark bars) 
cells at a sampling distance of $60 \mathrm{~cm}$ was only 9.2 for the highly susceptible cv. Cabernet Sauvignon, this ratio was 32.4 for Tampa; no vessels in Roucaneuf harbored moderate numbers of cells of $X$. fastidiosa (Table 1). Thus, both the numbers of vessels colonized by $X$. fastidiosa as well as the number of cells in a given colonized vessel are generally lower in resistant grape cultivars than more susceptible ones.

The recovery of lower number of culturable cells than expected in stems of resistant cultivars which had numbers of colonized vessels similar to those of susceptible cultivars could be due to a lower cell viability in the resistant plants. To test this possibility, we estimated the total number of cells of the gfp-marked strain of $X$. fastidiosa microscopically, based on the assumption that gfp fluorescence was persistent even in cells which had died. Given that we had made independent measures of both the incidence and extent of colonization of stem xylem vessels by $X$. fastidiosa by microscopy as well as direct measures of viable population sizes of $X$. fastidiosa by culturing of the adjacent tissue, we tested the model that cells of $X$. fastidiosa had similar frequencies of viability in different grape cultivars. We estimated population sizes in stems from microscopy measurements by multiplying the number of colonized vessels by the number of cells observed in a given vessel and with knowledge of the amount of plant material that had been examined during observation of cross-sections ( $28 \mu \mathrm{m} / \mathrm{section}$ by 12 cross-sections per sample). In sampling locations more proximal to the point of inoculation, the total populations estimated by microscopy were very similar to that of the culturable population, suggesting that most of the cells were viable, regardless of grape cultivar (Fig. 5). At a distance of $120 \mathrm{~cm}$ from the point of inoculation, the numbers of cells of $X$. fastidiosa estimated by microscopy were somewhat higher than the culturable populations in resistant cultivars. This is likely due to sampling issues because relatively few vessels were colonized by $X$. fastidiosa at such distances (Table 1), making accurate estimates of incidence and extent of colonization difficult and subject to stochastic variation due to sampling success. It seems likely that the underestimation of total populations in Cabernet Sauvignon and overestimation of total populations in Tampa at $120 \mathrm{~cm}$ relative to that estimated by culturing were both due to stochasticity in sampling of such infrequent colonization events at this distal site from the point of inoculation. Thus, it appears that most cells of $X$. fastidiosa were viable within plants, regardless of their location in the plant or the time the plant had been infected.

\section{DISCUSSION}

Although differences between the internal structure of stems and petioles of grape have been previously described $(11,13$, $14,27,28)$, it remains unclear why petioles appear to be preferred sites of development of large population sizes of $X$. fastidiosa. Stems have relatively few but large-diameter xylem vessels and many smaller tracheary elements. Petiole vessels are organized in clusters that are shorter and narrower that those in the stem. Leaves and petioles contain more narrow and terminal tracheary elements and shorter conduits (28). Petioles and leaf traces also have a higher proportion of parenchyma and tracheary elements than the stem. In contrast, vessel elements in the stem internodes had scalariform lateral-wall pits and simple perforation plates while vessel elements with helical secondary walls were predominant in leaf traces and petioles (27). The different structure of these pits in stem vessels may also be indicative of a differential susceptibility to degradation of $X$. fastidiosa that could account for the lower incidence of colonization of stem vessels compared with those in the petiole (Fig. 1). Similarly high population sizes of $X$. fastidiosa were seen in the petioles of susceptible Cabernet Sauvignon and Chenin Blanc cultivars as well as resistant Tampa and Roucaneuf cultivars. Similar results were obtained by Fry and Milholland $(11,12)$, who noted comparable $X$. fastidiosa popula-

\section{CABERNET SAUVIGNON}

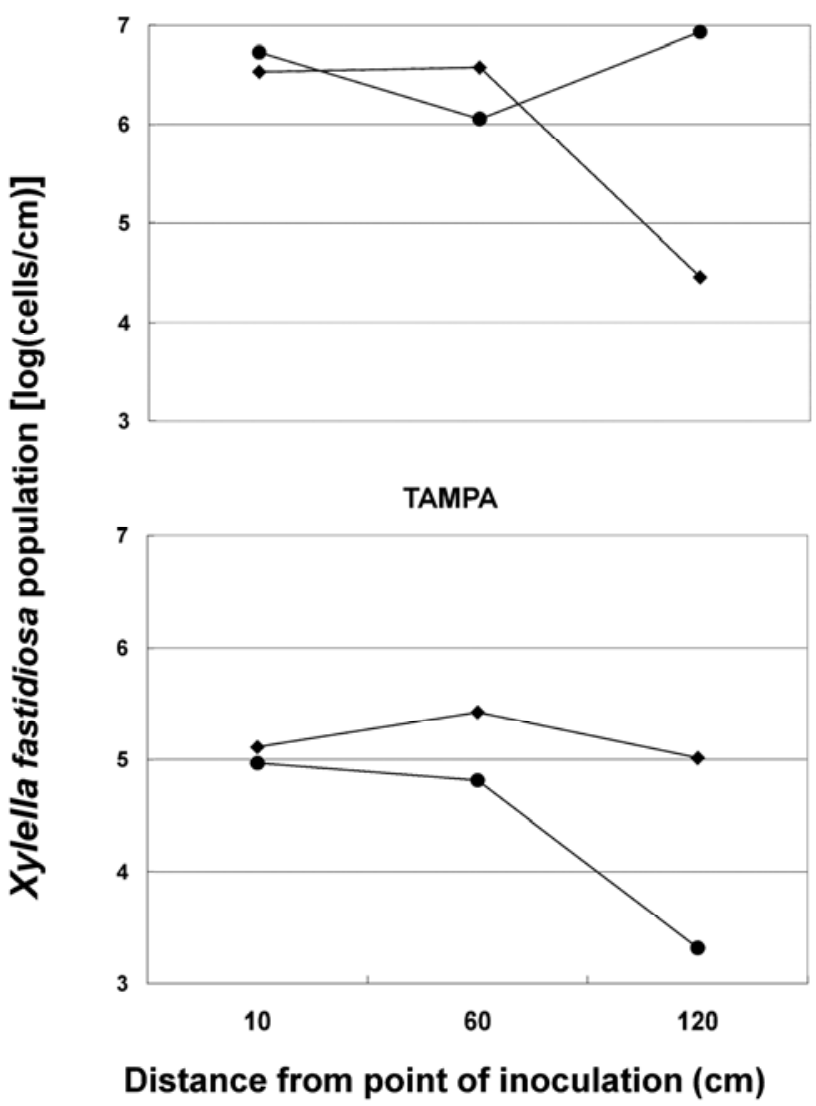

Fig. 5. Comparison of population sizes of a green fluorescent protein-marked strain of Xylella fastidiosa in the stems of the susceptible grape cv. Cabernet Sauvignon and the resistant cv. Tampa determined directly by culturing of tissue macerates $(-)$ or estimated from measures of colonization of xylem vessels by fluorescence microscopy $(\bullet)$. Plants were sampled at different distances from the point of inoculation (abscissa) at 11 weeks after inoculation.

TABLE 1. Differences in extent of colonization of stem xylem vessels in different grape cultivars determined by microscopic detection of a green fluorescent protein-marked strain of Xylella fastidiosa at different distances from the point of inoculation

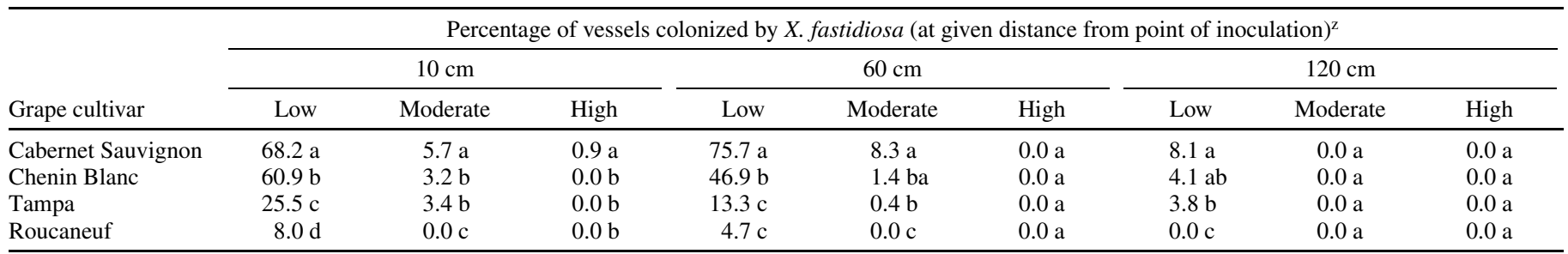

${ }^{\mathrm{z}}$ Percentage of vessels harboring a given number of cells of $X$. fastidiosa determined by fluorescence microscopy 11 weeks after inoculation. Means within a given column followed by the same letter do not differ $(P<0.05)$. Low $=$ vessels harbored few $X$. fastidios $a$ cells $(<10$ cells $)$, moderate $=$ vessels harbored a moderate number of $X$. fastidiosa cells $(>10$ but $<1,000$ cells), and high $=$ vessels harbored a large number of $X$. fastidiosa cells $(>1,000$ cells). 
tions in petioles of $V$. vinifera French Colombard (susceptible), $V$. rotundilofia Carlos (tolerant), and Noble grape (resistant) cultivars. In their studies, grape petioles were inoculated and subsequently sampled at different times after inoculation whereas, in our experiment, stems were inoculated and the petioles were sampled at various distances from the point of inoculation, requiring $X$. fastidiosa to disperse to the distal petioles. Krivanek and Walker $(16,17)$ also found no significant differences in $X$. fastidiosa populations in petioles and leaf blades by an enzymelinked immunosorbent assay (ELISA) method among resistant and susceptible cultivars following stem inoculation. Although Hopkins (14) repeatedly examined the incidence of infected vessels seasonally in a single cultivar, he found a lower percentage of infected vessels in the stems compared with petioles, which is consistent with our findings. It seems likely that such "natural" infestations of the petiole were initiated with fewer cells and, most likely, was initiated in fewer vessels than direct needle inoculation. Despite these differences in inoculation method, $X$. fastidiosa attained high population densities in petioles regardless of the degree of whole-plant resistance to PD, suggesting that resistance was not operative in leaves. Thus, resistance to movement of $X$. fastidiosa in different grape cultivars appears to be restricted to the stem tissue and is likely due to structural differences in the stem vessels of the resistant cultivars and is associated with a limitation of the number of vessels into which $X$. fastidiosa can spread and, therefore, in which they can grow. Resistance to PD is apparently not due to inhibitory compounds that circulate through the xylem because they might be expected to operate similarly in all tissues. Because $X$. fastidiosa was found in high numbers and high frequency within vessels of petioles, even in resistant cultivars and at some distance from the point of inoculation, it appears that $X$ fastidiosa follows a sinuous path up the vessels in the stem, colonizing relatively few vessels; however, when it enters the petiole, it can spread laterally to many more vessels and also multiply to high numbers.

The role of tyloses in the resistance of grape to PD remains unclear. It was intriguing to note that, whereas tyloses eventually were seen in all of the grape cultivars studied here, they appeared earlier in the resistant cvs. Tampa and Roucaneuf than in the more susceptible cultivars. Although tyloses could block movement of $X$. fastidiosa through the plant and, thus, could have been one of the contributors to a lower incidence of colonization, the movement of $X$. fastidiosa appeared to have been lower in the resistant cultivars even early during the infection process, before tyloses became abundant. Furthermore, it is unclear how the presence of tyloses could also explain the lower level of multiplication of $X$. fastidiosa in those vessels into which it had moved (Fig. 3).

The movement and multiplication of $X$. fastidiosa was quite different in stems of grape cultivars varying in resistance to PD despite no obvious structural differences in this study. In other studies, resistance to the movement of $X$. fastidiosa in different grape cultivars appeared also to be restricted to the stem tissues (17). Similar results were noted by Fry and Milholland (11), where the multiplication and movement of $X$. fastidiosa in the stems of French Colombard, Carlos, and Noble grape plants were found to be similar in the first few weeks after inoculation but increased in susceptible cultivars and decreased in resistant cultivars thereafter. Both studies suggest that multiplication is inhibited in resistant cultivars but successful in susceptible ones. These studies could not determine whether a lack of multiplication is the main cause of suppression of further movement or whether the lack of further movement is the primary cause of poor bacterial multiplication. Although viable $X$. fastidiosa population sizes in stems of the resistant Tampa and Roucaneuf cultivars was much lower than that in the susceptible Cabernet Sauvignon and Chenin Blanc cultivars (Fig. 3), the proportion of vessels harboring at least some cells of the pathogen did not differ nearly as much (Fig. 2). Thus, the relatively high population size of $X$. fastidiosa in susceptible cultivars was associated with substantially more multiplication that had occurred in those vessels that had become infested with the pathogen. Overall, $X$. fastidiosa invaded a smaller fraction of plant stem vessels and exhibited lower population densities in resistant cultivars. The finding that there is a nonlinear relationship between the population size of $X$. fastidiosa in stem tissue and the proportion of vessels that are colonized clearly indicates that multiplication was unequal within vessels in the different cultivars. This suggests that movement within stems and multiplication within stem vessels of resistant genotypes are both impaired and likely are co-dependent phenomena, unlike in petioles. Recent studies of the $r p f F$-dependent regulation of virulence of $X$. fastidiosa also have suggested that movement and multiplication in grape are linked (3-5). An RpfF mutant that is de-repressed for production of cell-walldegrading enzymes such as polygalacturonases both invaded more vessels and achieved a higher population size in infected tissues than the wild-type strain (4). Importantly, the increased population size of the $r p f F$ mutant (10- to 100-fold) compared with the wild type was much greater than the two- to threefold increase in the proportion of vessels that were colonized; such a nonlinear relationship between multiplication and movement between vessels is similar to that seen here with a wild-type strain in different grape cultivars. Presumably, the process of movement of $X$. fastidiosa from an infected vessel to other adjacent vessels involves the degradation of the pit membrane. This degraded plant material is apparently a source of considerable nutrition to $X$ fastidiosa (4). That is, those grape cultivars that are most easily digested by X. fastidiosa will be both more easily invaded and support more extensive multiplication by $X$ fastidiosa. Celldensity-dependent regulation of virulence in $X$. fastidiosa is mediated by the accumulation of a diffusible signal factor (DSF) produced by $\operatorname{RpfF}(20,26)$. DSF accumulation is associated with increased adhesiveness due to the expression of a variety of afimbrial adhesions and a decreased expression of cell-walldegrading enzymes such as polygalacturonases, as well as decreased expression of type IV pili associated with twitching motility. Thus, it appears that, at relatively low population sizes in a plant, $X$. fastidiosa expresses a suite of genes that are most consistent with active movement and multiplication whereas, when populations become higher, such virulence traits are suppressed (3). One can imagine that the pit membranes of resistant grape cultivars are less easily to be degraded or breached by $X$. fastidiosa and, hence, provide a poor nutritional resource for multiplication. Thus, the pathogen would not be able to achieve such high population sizes in resistant cultivars which, in turn, would enable the pathogen to remain in an active "exploratory" phase of plant colonization, unlike in more susceptible plants, where more extensive multiplication would lead to cessation of movement. Thus, in resistant cultivars, the pathogen, although perhaps moving to a few adjacent xylem vessels due to their recalcitrance to pit degradation, would continue to attempt to move within the plant due to their resultant low population sizes. It is apparent from this study that the relatively large populations in susceptible genotype stems are achieved because of both higher numbers of infected vessels and more extensive colonization of the vessels through which the bacteria move.

The fact that the population size of $X$. fastidiosa observed in susceptible cultivars was much higher than in resistant cultivars (higher than expected based on the proportions of infested vessels) (Fig. 3) raised the question of whether cells in the resistant cultivars may die as they age. Cells of many bacteria, including some plant pathogens, can enter a viable but nonculturable state upon exposure to certain stresses (21). It seemed possible that the environment of the resistant cultivars might constitute such a stress. Within the constraints on sampling imposed by the examination of a limited number of cross-sections of 
stem tissue, we found that the total population size estimated by microscopy was quite similar to the culturable population estimated following maceration of stem segments. Given that the half-life of the gfp marker protein that we used in this study is quite long and gfp fluorescence persists in cells even after they die (19), we would have expected more total cells to be estimated by counts of gfp-fluorescent bacteria than culturable cells if an appreciable proportion of the population of $X$. fastidios $a$ had died in the resistant grape cultivars. Because the culturable populations of $X$. fastidiosa in resistant grape cultivars were as much as 100fold lower than expected based on the proportion of stem vessels infested with the pathogen, such large numbers of dead cells should have been readily detected by our microscopic sampling. Thus, most cells of $X$. fastidiosa appear to be culturable within the time frames of the infections studied here.

The question of how infrequent blockage of vessels can lead to the pathology associated with $\mathrm{PD}$ has been asked since researchers have first studied it. A 4- to 10-fold difference in the incidence of vessel colonization between resistant and susceptible cultivars (to a maximum of $\approx 25 \%$ of the vessels in a given stem cross-section) may not appear to be enough to account for changes in the water transport in a plant. However, we believe that the complex pattern of interconnected vessels in the stem means that disruption of this network would not respond linearly to increased frequency of vessel blockage. Thus, one might expect increasing vessel blockage to lead to more than proportional reductions in water movement.

Examination of the extent of stem vessel colonization may prove to be a useful and high-throughput method to screen germplasm for resistance to PD. Estimations of total number of cells of $X$. fastidiosa in stems but not petioles are predictive of the disease resistance phenotype (17); however, culturing of the pathogen is relatively labor intensive, and other methods such as ELISA or quantitative polymerase chain reaction estimates of population sizes are either not very sensitive or suffer from background, especially at low population sizes. Examination of stem segments for the proportion of infested vessels and, especially, for the extent of colonization of the infested vessels may prove to be an expedient means to screen large numbers of plant genotypes because both will be expected to be low in resistant cultivars.

\section{LITERATURE CITED}

1. Aguero, C. B., Uratsu, S. L. Greve, C., Powell, A. L. T., Labavitch, J. M., Meridith, C. P., and Dandekar, A. M. 2005. Evaluation of tolerance to Pierce's disease and Botrytis in transgenic plants of Vitis vinifera L. expressing the pear PGIP gene. Mol. Plant Pathol. 6:43-51.

2. Alves, E., Marucci, C. R., Lopes, J. R. S., and Leite, B. 2004. Leaf symptoms on plum, coffee, and citrus and the relationship with the extent of xylem vessels colonized by Xylella fastidiosa. J. Phytopathol. 152:291297.

3. Chatterjee, S., Almeida, R. P. P., and Lindow, S. E. 2008. Living in two worlds: The plant and insect lifestyles of Xylella fastidiosa. Annu. Rev. Phytopathol. 46:243-271.

4. Chatterjee, S., Newman, K. L., and Lindow, S. E. 2008. Cell-cell signaling in Xylella fastidiosa suppresses movement and xylem vessel colonization in grape. Mol. Plant-Microbe Interact. 21:1309-1315.

5. Chatterjee, S., Wistrom, C., and Lindow, S. E. 2008. A cell-cell signaling sensor is required for virulence and insect transmission of Xylella fastidiosa. Proc. Natl. Acad. Sci. USA 105:2670-2675.

6. Choat, B., Ball, M., Luly, J., and Holtum, J. 2003. Pit membrane porosity and water stress-induced cavitation in four co-existing dry rainforest tree species. Plant Physiol. 131:41-8.

7. Esau, K. 1977. Anatomy of Seed Plants. Wiley \& Sons, New York.

8. Freitag, A. H. 1951. Host range of Pierce's disease virus of grapes as determined by insect transmission. Phytopathology 41:920-934.

9. Fritschi F. B., Lin, H., and Walker, A. A. 2007. Xylella fastidiosa population dynamics in grapevine genotypes differing in susceptibility to Pierce's disease. Am. J. Enol. Vitic. 58:326-332.

10. Fritschi. F. B., Lin, H., and Walker, M. H. 2008. Scanning electron microscopy reveals different response pattern of four Vitis genotypes to Xylella fastidiosa infection. Plant Dis. 92:276-286.

11. Fry, S. M., and Milholland, R. D. 1990. Multiplication and translocation of Xylella fastidiosa in petioles and stems of grapevines resistant, tolerant and susceptible to Pierce's disease. Phytopathology 80:61-65.

12. Fry, S. M., and Milholland, R. D. 1990. Response of resistant, tolerant, and susceptible grapevine tissues to invasion by the Pierce's disease bacterium Xylella fastidiosa. Phytopathology 80:66-69.

13. Hill, B. L., and Purcell, A. H. 1995. Multiplication and movement of Xylella fastidiosa within grapevine and four other plants. Phytopathology 85:1368-1372.

14. Hopkins, D. L. 1981. Seasonal concentration of the Pierce's disease bacterium in grapevine stems, petioles, and leaf veins. Phytopathology 71:415-418.

15. Hopkins, D. L. 1989. Xylella fastidiosa: xylem-limited bacterial pathogen of plants. Annu. Rev. Phytopathol. 27:271-290.

16. Krivanek, A. F., Stevenson, J. F., and Walker, M. A. 2004. Development and comparison of symptom indices for quantifying grapevine resistance to Pierce's disease. Phytopathology 95:36-43.

17. Krivanek A. F., and Walker, M. A. 2004. Vitis resistance to Pierce's disease is characterized by differential Xylella fastidiosa population in steams and leaves. Phytopathology 95:44-52.

18. Mollenhauer, H. H., and Hopkins, D. L.1976. Xylem morphology of Pierce's disease-infected grapevines with different levels of tolerance. Physiol. Plant Pathol. 9:95-100.

19. Newman, K. L., Almeida, R. P. P., Purcell, A. H., and Lindow, S. E. 2003. Use of a green fluorescent strain for analysis of Xylella fastidiosa colonization of Vitis vinifera. Appl. Environ. Microbiol. 69:7319-7327.

20. Newman, K. L., Almeida, R. P. P., Purcell, A. H., and Lindow, S. E. 2004. Cell-cell signaling controls Xylella fastidiosa interaction with both insects and plants. Proc. Natl. Acad. Sci. USA 101:1737-1742.

21. Oliver, J. D. 2005. The viable but nonculturable state in bacteria. J. Microbiol. 43:93-100.

22. Perez-Donoso, A. G., Sun, Q., Roper, M. C., Greve, L. C., Kirkpatrick, B., and Labavitch, J. M. 2010. Cell wall-degrading enzymes enlarge the pore size of intervessel pit membranes in healthy and Xylella fastidiosainfected grapevines. Plant Physiol. 152:1748-1759.

23. Purcell, A. H., and Hopkins, D. L. 1996. Fastidious xylem-limited bacterial plant pathogens. Annu. Rev. Phytopathol. 34:131-151.

24. Purcell, A. H., and Saunders, S. R. 1999. Fate of Pierce's disease strains of Xylella fastidiosa in common riparian plants in California. Plant Dis. 83:825-830.

25. Roper, M. C., Greve, L. C., Warren, J. G., Labovitch, J. M., and Kirkpatrick, B. C. 2007. Xylella fastidiosa requires polygalacturonase for colonization and pathogenicity in Vitis vinifera grapevines. Mol. PlantMicrobe Interact. 20:411-419.

26. Scarpari, L. M., Lambais, M. R., Silva, D. S., Carraro, D. M., and Carrer, H. 2003. Expression of putative pathogenicity-related genes in Xylella fastidiosa grown at low and high cell density conditions in vitro. FEMS Microbiol. Lett. 222:83-92.

27. Stevenson, J. F., Mathews, M. A., Greve, L. C., Labavitch, J. M., and Rost, T. L.. 2004. Grapevine susceptibility to Pierce's disease II: Progression of anatomical symptoms. Am. J. Enol. Vitic. 55:238-245.

28. Stevenson, J. F., Mathews, M. A., and Rost, T. L. 2004. Grapevine susceptibility to Pierce's disease I: Relevance of hydraulic architecture. Am. J. Enol. Vitic. 55:228-237.

29. Tyree, M. T., and Zimmermann, M. H. 2002. Xylem Structure and the Ascent of Sap. Springer-Verlag, New York.

30. Tyson, G. E., Stojanovic, B. J., Kuklinski, R. F., Divittorio, T. J., and Sullivan, M. L. 1985. Scanning electron microscopy of Pierce's disease bacterium in petiolar xylem of grape leaves. Phytopathology 75:264-269. 